\title{
Valorisation of energy services: essay on the value addition due to renewable energy
}

\author{
Yoram Krozer ${ }^{1,2,3}$
}

\begin{abstract}
The shift from fossil fuels and traditional renewable energy to costlier modern renewable energy based on geothermal wind and solar resources is explained.

Statistical data collected from 14 countries with a population greater than 100 million inhabitants was used, where the EU is considered as a country. The period from 1990 to 2015 is covered, however divided in two parts, 19902005 when conditions were not favourable for renewable energy because the price of fossil fuels and policy support for renewable energy were low, and 2005-2015 when these conditions improved.

Theoretical analyses show that the high price of fossil fuels, policy support and cost-effective technologies can explain the fast growth of modern renewable energy during 2005-2015; however, they only partially account for its slower growth during 1990-2005. An additional explanation might be that the innovators generate qualities due to renewable energy use, which are expressed on the markets as value addition of energy services. The statistical analysis of energy services during 1990-2005 shows that the European Union (EU) led in renewable energy compared to the United States (US), Japan and other countries, which was driven by the social initiatives that fostered new firms in the electricity and gas business. A statistical analysis of energy services in the US and EU during 2005-2015 reveals that their value added has grown on an annual average of $2.0 \%$ and $2.8 \%$, respectively, which denotes an annual increase of 3 billion and 6 billion US dollars in the 2005 value (USD 2005$)$. This valorisation of energy services has invoked further innovations in distributed energy systems and energy storage. A further statistical analysis of the 14 largest countries by population confirms a valorisation of energy services due to modern renewable energy where the emission reduction of carbon dioxide $\left(\mathrm{CO}_{2}\right)$ is a side-effect. Extrapolation of the average growth rates from the period 1990 to 2015 to the period 2015 to 2040, without any change but a substitution of fossil fuels for renewable energy, demonstrates that global income would grow fourfold and energy consumption twofold along with a 100 times larger modern renewable energy and $\mathrm{CO}_{2}$ reduction to $46 \%$ of the 2015 level. When those average growth rates of renewable energy decrease linear to 25\% in 2040, the global modern renewable energy grows tenfold and $\mathrm{CO}_{2}$ reduces to $82 \%$ of the 2015 level.

The implication of this statistical study on large countries shows that higher value energy services for households are often based on distributed renewable energy and that such an addition of value generates a $\mathrm{CO}_{2}$ emission reduction as a side effect which can be enhanced by pricing $\mathrm{CO}_{2}$ or obstructed by policy support for the vested interests. This study indicated that the valorisation of energy services will generate a growth of income, energy consumption and renewable energy along with a far-reaching emission reduction of $\mathrm{CO}_{2}$ if policies do foster sustainable innovations.
\end{abstract}

Keywords: Energy services, Value added, Energy consumption, Energy efficiency, Carbon dioxide

\footnotetext{
Correspondence: y.krozer@utwente.nl; krozer@xs4all.nl

${ }^{1}$ University of Twente, CSTM, Enschede, the Netherlands

${ }^{2}$ Jyothy Institute of Technology, Bangalore, India

Full list of author information is available at the end of the article
}

C) The Author(s). 2019 Open Access This article is distributed under the terms of the Creative Commons Attribution 4.0 International License (http://creativecommons.org/licenses/by/4.0/), which permits unrestricted use, distribution, and reproduction in any medium, provided you give appropriate credit to the original author(s) and the source, provide a link to the Creative Commons license, and indicate if changes were made. 


\section{Background}

Renewable energy increasingly rivals fossil fuels on the global energy market of 6400 billion US dollars in the 2005 value $\left(\mathrm{USD}_{2005}\right)$ a year because its consumption grows faster despite higher costs. Herewith, fossil fuels cover coal, oil, gas and nuclear resources, whereas renewable energy embraces the traditional, based on biomass and hydro resources, as well as modern renewable energy based on geothermal, wind and solar resources. World Bank data [1] show that the share of all renewable energy in global energy consumption has increased from $17 \%$ in 1990 to $18 \%$ in 2015 whilst total energy consumption has grown by $1.8 \%$ on an annual average. Within all renewable energy, modern renewable energy grew faster than the traditional one though it is costlier. In addition, the International Energy Agency (IEA) [2] reports that the share of the cheapest renewable energy, which is hydropower, have decreased whilst modern renewable energy, that is costlier, has grown by an annual average of $7.1 \%$ from $0.4 \%$ of the global energy supplies in 1990 to $1.5 \%$ in 2015. Businesses also perceived opportunities as global new investments in renewable energy grew nearly 100 -fold during the last 25 years from 4-10 billion $\mathrm{USD}_{2005}$ a year during $1990-2001$ to $280-$ 350 billion $\mathrm{USD}_{2005}$ a year during 2009-2015 [3], where most were channelled in modern renewable energy based on wind and solar power. This leaves one to question why a demand for more expensive renewable energy has grown and might still grow. This paper assesses the drivers of the growth of modern renewable energy. The assessment covers the period from 1990 to 2015 when modern renewable energy was substantially costlier than fossil fuels per energy unit measured by standardised discounting, manpower and other cost factors, referred to as the levelized costs of energy (LCOE) [4]. Although renewable energy has rarely reached price parity with fossil fuels in the deliveries for energy consumption in businesses and households (energy services) before 2015, it substituted fossil fuels. Apparently, factors other than the costs per energy unit were also important.

Why would households and businesses pay for costlier energy resources? The answer in this paper refers to the behavioural theory about transactions between suppliers and customers in the value chains, given their income [5]. If suppliers and customers operate under competition, these transactions evolve toward an equilibrium price of a specific quality and also generate novel qualities entailing a larger diversity of qualities within a framework of the suppliers' and customers' total income. The diversity of qualities enlarges because every subsequent supplier in a value chain compounds additional qualities in a product with the aim to sell these qualities at a higher product price or accrue a larger market share, whereas every subsequent customer pursues purchases of the qualities it perceives valuable after deliberations about deficiencies; please note that the deficiencies known to suppliers can be intangible to customers as the theory on asymmetric information on markets shows. The supply of those valuable qualities is expressed as value addition. The value added means sales minus purchases. The sales are equal to the sale price multiplied by the deliveries, and the purchases are the cost of resources multiplied by the volume of purchases. The value added is an expression of the marketable quality. It is formally:

$$
V_{\mathrm{i}}=\left(P_{\mathrm{s}, \mathrm{i}}-P_{\mathrm{r}, \mathrm{i}}\right) \cdot Q_{\mathrm{i}}
$$

where $V$ is the value added of services in monetary term, $P_{\mathrm{s}}$ is the sales price and $P_{\mathrm{r}}$ is the resource price, whereas $Q_{\mathrm{i}}$ denotes the quantity of the service in energy terms.

Novel qualities that are purchased by subsequent customers in the value chain and ultimately paid by consumers in households and businesses are considered as innovations. Innovations emerge due to novel entrepreneurial activities, labelled as "doing things differently" [6]. When these innovations add value to the individual interests as well as the collective, in particular when they reduce negative social and environmental impacts along with more income, they are labelled as sustainable innovations [7]. This train of thought about value chains and innovations holds also true for energy suppliers that process energy resources into energy services for customers in businesses and households. The supplies are diversified throughout the last two centuries into heat, power, motion, light, sound, vibration and other energy services. The value of some energy services increased a lot measured by market prices. For example, the international resource price of natural gas on the European Union market in 2015 was below USD 0.02 per kilowatt-hour (USD 6 per MMBtu). The Eurostat data [8] show that the sales prices to households after processing and distribution per kilowatt-hour were about USD 0.06 for gas and USD 0.14 for electricity without taxes, or USD 0.08 and USD 0.23 with taxes; the price of gas tripled and electricity increased about eight times. The value added of gas services was $(0.06-0.02) \times 1146$ $\mathrm{TWh} \approx$ USD 46 billion and electricity services $(0.14$ $0.02) \times 3458 \mathrm{TWh} \approx$ USD 414 billion in nominal prices, $\mathrm{TWh}=10^{6} \mathrm{kWh}$. More detailed accounts are shown in "Valorization of energy services" section. In this paper, the growth of modern renewable energy is comprehended as an innovation spur for the valuable qualities in energy services when aiming at private and collective interests.

Customers do pay for additional qualities and fewer deficiencies in energy services because they contribute to productivity and welfare [9]. For example, higher qualities of energy services generate spin-off in production due to high caloric heat for industries, high power 
for mobility, electricity for air conditioning and other income-generating activities. High-quality energy services contribute to welfare due to lighting for education, sound for leisure and other private interests, as well as to fewer hazards, pollution reduction and other social interests. The income per unit energy service is referred to as the energy intensity by the World Energy Council (WEC); in engineering, it is often defined as the energy input per product quantity. Energy intensity grew globally on average by $1 \%$ to $3 \%$ per year throughout the past decades [10]. Modern renewable energy also adds valuable qualities to energy services. For example, renewable energy provides more transparent supply chains, and when local resources are used, it enables energy consumption in remote areas, and it is used as a backup for peaks in energy demands because the production capacities for the baseload can be lower. In addition to such private interests, modern renewable energy also contributes to the common good because hazards of combustion, pollution and emissions of carbon dioxide $\left(\mathrm{CO}_{2}\right)$ that cause climate change are reduced. These qualities add value to energy services. There are also deficiencies because renewable energy based on wind and solar power is variable. Continuous electricity delivery needs storage. That major deficiency of modern renewable energy, which is the variability of energy supply in time and space, is countered by local networks for heat and power with energy storage in water power, electric batteries, pressed hydrogen and other means, as well as exchange of the energy surplus across customers, referred to as distributed energy systems. The cost of storage, however, is high and adds to present electricity prices. The growth of value added in energy services during several years indicates a stream of novel valuable qualities, referred to as the valorisation of energy services. The valorisation of energy services and the role of modern renewable energy in it are estimated in this paper.

Mainly, statistical data are used. These are derived from the Energy Information Administration (EIA) for the United States [11] and the Eurostat data for the European Union, as well as the World Bank and IEA data. The data cover 14 countries with more than 100 million inhabitants in 2017 and globally. The income per capita after correction for inflation based on a typical consumer purchase basket is used, referred to as gross domestic product in purchasing price parity (GDP-PPP). These countries in ascending order GDP-PPP per capita in 2015 are the USA, Japan and European Union of 28 members (which are considered high-income countries), followed by the Russian Federation, Mexico, Brazil, China, Indonesia, Philippines and India (which are called mid-income countries), and finally, Nigeria, Pakistan, Bangladesh and Ethiopia (which are considered as low-income countries). Using the IEA data for 2015, these countries together covered about $70 \%$ of the global population, $74 \%$ of the global GDP-PPP, $65 \%$ of the global energy production, $72 \%$ of the energy consumption and $76 \%$ of the electricity consumption, as well as $88 \%$ of coal supplies, $63 \%$ of oil, $64 \%$ of gas, $83 \%$ of nuclear energy, $71 \%$ of biofuels, $66 \%$ of hydropower, $84 \%$ of modern renewable energy and $73 \%$ of the global $\mathrm{CO}_{2}$ emissions. For this paper, only public data are used because they are assumed more credible compared to the data published by private sources and the data sources are not mixed in the accounts in order to avoid data discrepancies between different data sources. This is done because differences in the public data sources can be found. For example, compared to the World Bank data in 2015, the IEA data show a $4 \%$ lower global energy consumption, $12 \%$ lower global $\mathrm{CO}_{2}$ emissions and much larger differences for a few countries; the countries' data also differ from the international data.

The period 1990-2015 is considered. The assessment encompasses the timeframe from 1990 to 2005 when the prices of fossil fuels fluctuated around $\mathrm{USD}_{2005} 30$ per barrel oil equivalent (b.o.e.) and from 2005 to 2015 when the prices fluctuated around $\mathrm{USD}_{2005} 100$ per b.o.e; the oil price is a usual benchmark for prices of all energy resources [12]. These fuel prices are equivalents of USD 10 per ton $\mathrm{CO}_{2}$ and USD 35 per ton $\mathrm{CO}_{2}$ in the fuel mix of 2015 based on IEA emission factors of 3.80 tons $\mathrm{CO}_{2}$ per ton coal, 2.53 tons $\mathrm{CO}_{2}$ per ton oil and 2.16 tons $\mathrm{CO}_{2}$ per ton oil equivalent of gas [13]; all other energy resources are assumed to cause nil $\mathrm{CO}_{2}$ emissions. Fossil fuels and renewable energy are rivals in the energy markets which implies that low prices of fossil fuel impede sales of renewable energy and high prices enhance it. Hence, these subsequent periods point to a growth in renewable energy in times of unfavourable international prices of energy resources and favourable ones, respectively. Given that the growth rates of a particular novelty can initially be high but decrease after several years, the annual average growth during 10 years or more is assessed and the sum of geothermal, wind and solar energy is considered. All prices are calculated in real $\mathrm{USD}_{2005}$, the growth rates denote annual averages, and all regressions represent Pearson correlations across 14 countries and globally $(n=15)$. "Appendix 1" shows several global indicators in 2015 and growth rates based on the IEA data in 5 year intervals.

The valorisation of energy services is explained in the "Explanations of the substitutions" section. It is a new subject as references to the valorisation of energy services are scarce. Valorisation sheds light on important drivers of innovations in energy markets. The valorization of energy services is empirically underpinned for the USA and European Union in the "Valorization of energy services" section. It is shown that 
the demands for renewable energy generate high value and incentives for innovation even if this is only detectable in market niches during several years right after the introduction of the innovation. Valorization across countries and impacts on $\mathrm{CO}_{2}$ emissions are indicated in the "Global valorisation trends" section. It is illustrated that the demands, when fostered by public policies, contribute to far-reaching reductions of $\mathrm{CO}_{2}$ emissions. It is an encouraging message for policies regarding climate change. The conclusions are drafted in the "Discussion and conclusion" section.

\section{Explanations of the substitutions}

The valorisation of energy services can be explained from the mainstream perspective that is focused on prices, from the evolutionary viewpoint that underlines the development in knowledge and from the behavioural perspective that addresses entrepreneurial activities. These viewpoints about general drivers of innovation are not discussed as they are reviewed in another paper [14]. The explanations are presented sequentially though arguments are partly complementary.

\section{Mainstream explanations}

In the mainstream (neo-classic) economic theory, price competition is assumed to invoke innovations on energy markets. Price competition drives firms toward more efficient allocation of energy resources which implies an introduction of cheaper technologies whenever feasible. Cheaper technologies enable lower costs of energy consumption. This viewpoint is underpinned with observations that the vested energy technologies are substituted for novel, cheaper new technologies called backstop technologies [15]. This is also underpinned by assessments of the international prices of energy resources which show decreasing trends of prices throughout the last century, when these prices are corrected for inflation, periodical fluctuations and the global fuel mix [16]. In the mainstream view, the competition drives the energy markets toward lower prices, whereas costlier energy services are assumed to indicate market imperfections caused by cartels, policy interventions, and other distortions of the competition.

Price peaks in energy resources are attributed to cartels. As long as the competition on energy markets prevailed, international oil prices fluctuated within the range of $\mathrm{USD}_{2011} 15-40$ per b.o.e. throughout the 1900s until 1982 when prices peaked at $\mathrm{USD}_{2011} 100$ per b.o.e. because the oil-producing countries agreed to restrict oil production. Prices dropped to the previous level by 1989 due to competition but increased again to $\mathrm{USD}_{2011} 100$ per b.o.e. during 2010-2015 when the demands for energy grew much faster; the prices fell thereafter [17]. The first peak of energy prices invoked modern renewable energy technologies: modern biofuels, wave energy, wind power, photovoltaics, solar thermal energy, etc.
High prices of fossil fuels are also important for the growth of renewable energy thereafter, but this is an insufficient explanation. It is observed that modern renewable energy grew globally by $4.4 \%$ on average compared to a $1.8 \%$ growth of energy consumption from 1990 to 2005 when prices of fossil fuels were low; though in times of high prices from 2005 to 2015, the modern renewable energy grew by $11.1 \%$ compared to a $1.7 \%$ growth of energy consumption. Moreover, modern renewable energy was costly although its unit costs decreased.

Policy support for renewable energy would also drive that growth. No doubt that policy support for renewable energy is important. However, the total policy support for fossil fuels was several times larger than for renewable energy though it was smaller per energy unit because the consumption of fossil fuels was several times larger. During low prices of fossil fuels, only a few countries subsidised renewable energy and these subsidies fluctuated depending on the policy priorities [18]. During high fuel prices energy subsidies covered nearly USD 487 billion on average per year, and among them, nearly $80 \%$ are in support of fossil fuels [19]. All global policy support for energy services, which covers on-budget subsidies as well as tax exemptions, price guarantees, soft loans and other off-budget support, approached USD 1.900 billion in 2010, by and large for fossil fuels [20]; it was even USD 5.300 billion including the costs for environmental damage [21].

The European Union, that championed renewable energy consumption throughout the assessment period, supported fossil fuels with USD 31 ( $€ 23.9)$ billion and renewable energy with USD 6.9 ( $€$ 5.3) billion in 2001 when the prices of fossil fuels were low [22]. The annual average support of the European Union increased to USD 129 ( $€$ 99.4) billion for fossil fuels and USD 39 ( $€$ 30 billion) for renewable energy during the times of high fuel prices of 2008-2015 [23]. The support for fossil fuels was five times larger than that for renewable energy during low prices and three times larger during high prices, albeit smaller per kilowatt-hour. The main policy support for renewable energy in the European Union was a price guarantee called feed-in tariff, which was a minimum price per supplied unit of renewable energy. During times of low fuel prices, the feed-in tariffs rarely covered all additional costs needed to attain price parity with fossil fuel based on LCOE; an exception was the high feed-in for wind power in Denmark which gave boost to its global leadership in wind energy. During high fuel prices, several countries introduced higher feed-in tariffs for price parity in wind power, biogas and small hydropower, as well as high feed-in tariff for solar power in Germany and other countries [24]. Policy support was essential for the growth of modern renewable energy in several front-running countries but cannot 
explain the global growth of modern renewable energy during the low price levels of fossil fuels. Larger policy support for renewable energy along with the high prices for fossil fuels can largely explain the faster growth of renewable energy within 2005-2015.

The preoccupation with prices in the mainstream viewpoint is disputed with regard to the unpredictable demands, deficient information and other non-price factors. In the evolutionary viewpoint, energy prices are relevant within an institutional framework [25], in particular, the market formation and organisation, knowledge and technology development [26]. For instance, the biomass substitution for coal during the nineteenth century in the UK is assessed to be driven by a larger public income, knowledge and education, as well as cooperation within the industries and new technologies, all these in addition to the prices [27]. Progress in science and engineering, it is argued, generates effective energy resources. This is indicated by a higher energy density in the resources due to more hydrogen per carbon in the fuel mass, e.g. more in gas compared to coal, referred to as decarbonisation [28]; or by a higher density of electrons in power is pinpointed, e.g. nuclear power compared to hydropower. Decarbonisation implies, for instance, that a nearly twice higher ratio of hydrogen per carbon in gas than in coal generates more heat. A global decarbonisation of energy resources throughout the last centuries is argued in terms of the substitutions of carbon-intensive peat and biomass for less carbon-intensive coal, and thereafter coal for oil and gas, followed by low-carbon nuclear and finally for modern renewable energy [29]. The decarbonisation of the energy resources, however, is not always expressed in energy services. For instance, one would expect a faster growth of nuclear power compared to that of coal throughout the last 25 years but the opposite is observed. Similarly, modern renewable energy has grown fast although it is often considered to be of low density and a variable energy resource [30]. Apparently, other factors also play a role.

Annual decrease of cost per unit energy resource is also identified as a driver of growth, referred to as the cost-reducing technological change. The drivers of change differ. Studies on the development of photovoltaic technologies (PV) during the 1980s and 1990s suggest that the knowledge spillovers between firms that developed PV determined the rate of change; these spillovers are considered to be unintended exchanges of the firms' know-how [31]. Studies on the market introduction and dissemination of PV underline that the economy of scale in sales is the driver of cost reduction as a larger scale enables a standardisation in the manufacturing of PV [32]. Both viewpoints can be valid during those different phases of innovations. However, these arguments do not explain the large efforts in technology development and market introduction of PV during the 1990s when fuel prices and policy support were low because sales of PV were uncertain, and therefore, such efforts were risky. They also do not explain the differences in the rate of change across technologies. The rate of change varies across energy resources, for example, the increasing unit costs of nuclear power versus the decreasing unit costs of gas, although both consumption rates have grown. The highest rate of change is in modern renewable energy [33].

The mainstream and evolutionary explanations focus on market and institutional conditions for renewable energy. High market prices of fossil fuels, larger policy support for renewable energy and more cost-effective technologies created favourable conditions for a faster growth of modern renewable energy during 2005-2015 but do not explain the growth during 1990-2005 when all these factors were not favourable. This implies that the energy services that delivered modern renewable energy were attractive to the growing number of customers even under unfavourable conditions. Such services have grown even faster when conditions are improved.

\section{Innovative performance}

The additional explanation refers to entrepreneurs that pursue innovations in energy services when they expect that their novel qualities are going to be purchased because the purchasers can generate benefits due to these novelties. Sales of renewable energy, herewith, are generated when perceived valuable by customers because costlier energy services are expected to be outweighed by the benefits of deliverable qualities for the individual and collective uses. Several benefits of renewable energy, including energy storage, are shown in Additional file 1 along with references. They are divided into the producers' and consumers' benefits for individual and collective goods. Possible producers' benefits are, for example, spread of financial risks and better grid management. For the producers, collectively, these are lower price volatility, fewer energy losses, deferring high-voltage infrastructure, reuse of polluted areas and so on. Individual consumers can gain when monopolies are avoided, power is guaranteed and peaks in demand are reduced, and the consumers' communities can generate tax income, generate jobs, reduce $\mathrm{CO}_{2}$ emission, etc. It is observed that renewable energy production reduces spot prices on electricity markets [34] [35], and its consumption enhances the income growth in high-income countries (OECD) [36] and global trade [37]. However, specifications of the costs, benefits and conditions for high benefits have rarely been assessed. This omission needs more research.

An important issue for the explanation of the innovative performance and for policies aiming at fostering 
innovations is whether those innovators in energy services who have taken the risk of introducing costly modern renewable energy were firms from within the electric and gas business or were newcomers to the energy markets. Therefore, the innovative performances of electric and gas businesses in the USA, Japan and European Union are compared based on their shares in modern global renewable energy during $1990-2005$, this is during the unfavourable conditions for renewable energy, and during 2005-2015, which means when conditions have improved. The countries' total shares in global renewable energy were $72 \%$ and $60 \%$ within these periods. Based on IEA data, Table 1 shows the countries' supplies in terawatt hours of geothermal energy, wind power, solar power from photovoltaic (PV) and solar thermal energy, as well as their share in global supplies in 1990, 2005 and 2015. During 1990-2005, geothermal supplies grew slowly and solar thermal stagnated compared to the growth of wind power and PV; a faster growth of power than that of heat could be a reflection of the higher value. In 1990, the USA led in geothermal resources and wind power but lost these shares by 2005, as well as its share in solar thermal by 2015 ; its focus on thermal resources during 1990-2005 was not successful. Japan led in PV during 1990-2005 but lost its share when conditions improved because of failing PV adoption in Japan. The European Union enlarged its share in wind power and also maintained a high share in PV and geothermal energy during 1990-2005. Its share in PV and solar thermal enlarged from 2005 to 2015 but decreased in wind power as mid-income countries captured a larger share of the global wind market. The EU captured a larger market share during unfavourable conditions and maintained it thereafter.

The success of the European Union during 1990-2005 compared to the USA and Japan was not driven by resource prices because they are international, nor by large policy support because it was rarely sufficient to cover all costs, or by cost-effective technologies for renewable energy because they were generally costlier than rival technologies based on fossil fuels and all those were internationally traded. Moreover, as measured by the number of jobs, which is a conventional indicator of long-term business performance, the electric and gas business in the European Union performed poorly compared to the USA [38]; the data on Japan in English is unfortunately insufficient [39]. Table 2 presents the number of jobs in all industries and in the electric and gas businesses in the USA and the European Union in 2015, as well as the average annual changes in employment and their annual job equivalents during 19992005 and 2005-2015; earlier Eurostat data for the European Union are not reliable. In 2015, the European Union employed twice as many people in the electric and gas business as the USA, although employment in all other businesses was similar. When the European Union captured a high share of global modern renewable energy during 1999-2005, its electric and gas business lost per year $-3 \%$ of all jobs compared to only $-1 \%$ in the USA. These declines were equivalent to 35,000 lost jobs and 8000 lost jobs, respectively. The innovativeness of energy firms in the European Union is also assessed inferior to the USA, measured by research and development [40] and market value [41] in 2005. The vested electric and gas business did not contribute to the successful growth of renewable energy in the European Union.

Newcomers to energy markets generated innovations. Social initiatives were instrumental for the success in 1990-2005 because they constructed equipment based on renewable energy technologies, for instance, modern windmills and PV panels on roofs, and fostered the purchases of renewable energy in communities under unfavourable conditions. An important motive for those purchases was local employment and income because local energy resources could be employed [42]. Benefits to the local economies motivated stakeholders across various European regions to arrange networks that pursued local knowledge, business start-ups and jobs in renewable energy [43]. For instance, the success of wind power in Denmark is largely attributed to the local cooperatives and farmers being facilitated by tax exemptions. Similarly, the introduction of PV in Germany was mainly generated by communities despite the low feed-in tariffs during that time. Many social initiatives dissolved but some evolved into successful firms, such as Ecopower in Belgium that started in 1991 as a small group of anti-nuclear activists aiming at "alternative energy" with one windmill and evolved into a cooperative of more

Table 1 Shares of modern renewable energy in the United States (US), Japan and European Union (EU)

\begin{tabular}{|c|c|c|c|c|c|c|c|c|c|c|c|c|}
\hline \multirow{2}{*}{$\begin{array}{l}\text { TWh }=10^{6} \\
\mathrm{kWh}\end{array}$} & \multicolumn{4}{|l|}{1990} & \multicolumn{4}{|l|}{2005} & \multicolumn{4}{|l|}{2015} \\
\hline & TWh & US (\%) & Japan (\%) & EU (\%) & TWh & US (\%) & Japan (\%) & EU (\%) & TWh & US (\%) & Japan (\%) & EU (\%) \\
\hline Geotherm. & 36 & 44 & 5 & 9 & 58 & 29 & 6 & 9 & 80 & 23 & 3 & 8 \\
\hline Wind power & 4 & 79 & 0 & 20 & 104 & 17 & 2 & 68 & 838 & 23 & 1 & 36 \\
\hline Solar PV & 0 & 14 & 5 & 57 & 4 & 13 & 38 & 37 & 247 & 13 & 15 & 42 \\
\hline Solar therm. & 1 & 100 & 0 & 0 & 1 & 100 & 0 & 0 & 9 & 38 & 0 & 59 \\
\hline Total & 41 & 48 & 4 & 10 & 167 & 21 & 4 & 46 & 1174 & 21 & 4 & 35 \\
\hline
\end{tabular}


Table 2 Jobs in all enterprises and in the electric and gas utilities in the USA and European Union

\begin{tabular}{|c|c|c|c|c|c|c|}
\hline & \multicolumn{2}{|l|}{2015 in millions } & \multicolumn{2}{|c|}{ Period 1999-2005 } & \multicolumn{2}{|l|}{ Period 2005-2015 } \\
\hline & All establishments & Electric and gas business & Growth rate (\%) & Annual job equivalents & Growth rate (\%) & Annual job equivalents \\
\hline USA & 124 & 0.6 & -1 & -7934 & 0 & 2261 \\
\hline European Union & 142 & 1.3 & -3 & $-35,318$ & 1 & 25,914 \\
\hline
\end{tabular}

than 50,000 members with $5 \%$ share of the Belgian power market in 2015 .

When the conditions improved during 2005-2015, many social initiatives turned to business, and new firms entered markets, which was expressed in the statistics as a high birth rate of firms. During 2007-2014, more data is unreliable, an exceptionally high birth rate of firms is observed in the electric and gas business in the European Union; that rate was low in the USA although both experienced a financial crisis in 2008 and the financial support of renewable energy business in the USA was as large or even larger though precise statistical data are unavailable. Regarding low cross-country correlations of the birth-rate growth with feed-in tariffs growth in the European Union and even the negative ones with energy intensity, the high birth of firms cannot solely be attributed to policy support or economic development but should also be attributed to the growing entrepreneurial capabilities of the social initiatives and new firms [44]. The emergence and growth of innovating firms in renewable energy is an important subject for policy making which needs more research.

The growth of modern renewable energy can be comprehended as an innovation spur aiming at beneficial energy services. Trailblazing innovators in the European Union were particularly successful during unfavourable conditions due to social initiatives and newcomer firms to energy markets which fostered technology development and purchases of renewable energy in communities. Social initiatives triggered the birth and growth of new firms in the electric and gas business when the conditions for renewable energy were improved.

\section{Valorization of energy services}

Regarding the high market shares of renewable energy and its fast growth during 2005-2015 in the USA and European Union, the valorisation of energy services in these countries is estimated. The data of Energy Information Administration (EIA) is used for the USA (https://www.eia.gov/electricity/annual/) and the Eurostat data for European Union. The estimates are focused on electricity services, because of their higher value than that of heat services. The valorisation is calculated in the following way:

$$
\begin{aligned}
& \text { growth } g_{\mathrm{t}}=v_{\mathrm{t}+1} / v_{\mathrm{t}} \\
& \quad \text { value added } v_{\mathrm{t}}=p_{\mathrm{s}, \mathrm{t}} \times q_{\mathrm{s}}-p_{\mathrm{r}, \mathrm{t}} \times q_{\mathrm{r}}
\end{aligned}
$$

for the resources volume $q_{\mathrm{r}, \text { total }}=q_{\mathrm{t}, \text { coal }}+q_{\mathrm{t}, \mathrm{oil}}+q_{\mathrm{t}, \mathrm{gas}}$

$$
\begin{aligned}
\text { resource prices } p_{\mathrm{r}, \mathrm{t}} & =p_{\mathrm{t}, \text { coal }} \times q_{\text {coal }} / q_{\text {total }}+p_{\mathrm{t}, \mathrm{oil}} \\
& \times q_{\mathrm{oil}} / q_{\mathrm{total}}++p_{\mathrm{t}, \mathrm{gas}} \times q_{\mathrm{gas}} / \mathrm{q}_{\mathrm{total}}
\end{aligned}
$$

and real prices $p_{\mathrm{t}}=p_{\mathrm{t}} / p_{2005}$ and $p_{\mathrm{t}}=p_{\mathrm{t}, \text { euro }} / p_{\mathrm{t}, \text { usd }}$

The value addition is assessed as the annual sale prices of electricity multiplied by the delivery volume (sales) minus the annual purchase cost of an energy resource multiplied by the resources mix for electricity generation (purchases). The purchase quantities are the sum of coal, oil and gas purchases. The purchase prices are weighed for the share of resource quantity in total. All prices are deflated to 2005, and euros are converted into dollars. The following data are used. The resource prices are based on the international prices of coal, oil and gas in the USA $^{1}$ and assumed applicable to the European Union because such data is unavailable in its statistic. The fuel mix is country-specific. The sales prices are an average of all households and businesses in the USA, as well as mid-size households and mid-size firms in the European Union, both in $\mathrm{USD}_{2005}$ including profit and tax. The deliveries cover all households and businesses in terawatt hour.

\section{Electricity deliveries}

The valorisation of energy services is observed in households but not in businesses, which holds true for the USA and European Union. Table 3 shows the prices of purchases and sales, as well as the value added for services to households and businesses in the USA and European Union from 2005 to 2015.

The cost of electricity to households was on average 10 times higher than the purchase prices of energy resources in the USA and 31 times higher in the European Union; all, including taxes, were 6 and 16 times higher in businesses. Consumers are ready to pay a lot for energy services. The purchase costs decreased by $-2.7 \%$ on average in the USA and $-2.4 \%$ in the European Union, whereas their difference reflects fuel mixes. The cost to households increased by $1.7 \%$ on an annual 
Table 3 Purchase prices, sale prices and production value of deliveries to households and industries in USA and European Union during 2005-2015, accounted using the formulae above

\begin{tabular}{|c|c|c|c|c|c|c|c|c|c|c|}
\hline \multirow{2}{*}{$\begin{array}{l}\text { USD }_{2005} \\
\text { Years }\end{array}$} & \multicolumn{2}{|c|}{$\begin{array}{l}\text { Purchases USD/ } \\
\text { kWh }\end{array}$} & \multicolumn{2}{|c|}{$\begin{array}{l}\text { Household sale price } \\
\text { USD/kWh }\end{array}$} & \multicolumn{2}{|c|}{$\begin{array}{l}\text { Industrial sale price } \\
\text { USD/kWh }\end{array}$} & \multicolumn{2}{|c|}{$\begin{array}{l}\text { Value added household } \\
\text { USD billion }\end{array}$} & \multicolumn{2}{|c|}{$\begin{array}{l}\text { Value added industry } \\
\text { USD billion }\end{array}$} \\
\hline & USA & $E U$ & USA & $E U$ & USA & EU & USA & $E U$ & USA & $E U$ \\
\hline 2005 & 0.011 & 0.007 & 0.095 & 0.17 & 0.06 & 0.08 & 113 & 253 & 47 & 87 \\
\hline 2006 & 0.010 & 0.007 & 0.101 & 0.17 & 0.06 & 0.09 & 123 & 269 & 50 & 96 \\
\hline 2007 & 0.010 & 0.006 & 0.100 & 0.20 & 0.06 & 0.11 & 125 & 316 & 51 & 114 \\
\hline 2008 & 0.013 & 0.008 & 0.104 & 0.21 & 0.06 & 0.12 & 126 & 347 & 52 & 124 \\
\hline 2009 & 0.010 & 0.006 & 0.106 & 0.21 & 0.06 & 0.12 & 131 & 341 & 49 & 110 \\
\hline 2010 & 0.010 & 0.006 & 0.105 & 0.20 & 0.06 & 0.11 & 137 & 341 & 50 & 106 \\
\hline 2011 & 0.010 & 0.007 & 0.104 & 0.22 & 0.06 & 0.11 & 134 & 365 & 50 & 111 \\
\hline 2012 & 0.008 & 0.007 & 0.104 & 0.21 & 0.06 & 0.11 & 131 & 351 & 49 & 101 \\
\hline 2013 & 0.009 & 0.006 & 0.104 & 0.23 & 0.06 & 0.11 & 132 & 379 & 49 & 100 \\
\hline 2014 & 0.010 & 0.006 & 0.105 & 0.23 & 0.06 & 0.10 & 135 & 370 & 50 & 96 \\
\hline 2015 & 0.008 & 0.005 & 0.105 & 0.20 & 0.06 & 0.08 & 137 & 321 & 49 & 76 \\
\hline Annual average growth & $-2.7 \%$ & $-2.4 \%$ & $1.1 \%$ & $2.0 \%$ & $0.1 \%$ & $0.3 \%$ & $2.0 \%$ & $2.8 \%$ & $0.5 \%$ & $-0.7 \%$ \\
\hline
\end{tabular}

average in the USA and $2.0 \%$ in the European Union and the delivery by $0.4 \%$ and $0.6 \%$, respectively. Hence, the value added grew per year by $2.0 \%$ on average in the USA and $2.8 \%$ in the European Union, which are equivalents of an additional USD 20052 billion and $\mathrm{USD}_{2005} 7$ billion per year, respectively. The value added of energy services to industries grew on average by $0.5 \%$ in the USA and declined $-0.7 \%$ in the European Union, whereas delivery decreased when cost increased, which provides yearly equivalents of $\mathrm{USD}_{2005} 0.2$ billion and $\mathrm{USD}_{2005}-1.0$ billion, respectively. Modern renewable energy grew faster than all deliveries of electricity. In the USA, solar energy delivery grew by $75 \%$ on annual average up to $1.39 \mathrm{TWh}$ and wind power by $44 \%$ up to 30 TWh in 2015; together, they accounted for $2.3 \%$ of the electricity consumption in 2015. In the European Union, solar energy delivery grew by $33 \%$ on average up to 152 TWh and wind energy by $16 \%$ on average up to 302 TWh, which accounted for $27 \%$ of the electricity consumption in 2015. Geothermal energy is rarely used for electricity generation but is increasingly used for heating.

These findings are counterintuitive. A conventional argumentation is that higher prices reduce deliveries; price elasticity of demands for energy resources is estimated to be on average -0.4 in the short run and -0.7 in the long run across various studies [45], respectively. However, the sales prices of electricity to households increased throughout 2005-2015 on average per year in the USA and European Union, whereas the prices of energy resources for the electricity generation decreased. These changes generated higher value added, which evolved along with fast growth of the deliveries of modern renewable energy to households but the growth of value added is not observed for the deliveries to businesses. A challenge is whether the growing value added of energy services to households can be explained by imperfections in the energy markets or by the deliveries of modern renewable energy as innovative energy services; the latter is possible because it is observed that innovations in energy markets do generate higher prices and deliveries [46]. These alternative explanations are discussed subsequently.

A market imperfection can be caused by behavioural slack. Sluggish energy savings when prices increase are observed in industries [47], but this study shows a sensitivity to higher electricity prices. Slack is also observed at households when personal income grows as long as the energy costs remain below $6 \%$ of the income [48], but personal income decreased in the USA and stabilised in the European Union from 2005 to 2015 as estimated using the World Bank data. An imperfection can be that the subsidies are not reflected as lower prices but such ripple effects of policies disappearing after a few years on the markets under competition. Competition in the energy markets increased in the European Union due to privatisation, high birth rate of new energy firms and the decreasing share of the largest electricity producer, with the exception of Denmark, Germany and Austria where local public firms merged and in the UK where private firms merged. Monopoly prices may have been found in the USA because firm scales are larger and birth rates of firms are lower, and subsequently, sales prices grew slower than in Europe. Taxes have hardly increased in the European Union if based on estimates of electricity prices during 2008-2015 with and without taxes. These estimates show that taxes rarely exceed $20 \%$ of the average consumer price in the European Union, although it 
is a rough estimate as the prices and taxes hugely vary in time, per country and per scale of energy consumption ${ }^{2}$. As only the total consumption is shown in the statistics, the shares per scale in total consumption are estimated ${ }^{3}$. It is found that the sum of taxes did not increase in time. The value added without taxes grew even faster than with taxes: $4.1 \%$ in households and $2.6 \%$ in business without taxes compared to $2.8 \%$ and $-0.7 \%$ with taxes, respectively. This data is not found for the USA. Slack, income growth and taxes do not explain the value-added growth.

Modern renewable energy plausibly added value. The growing value added of energy services in households is correlated to the growth of renewable energy consumption during the period from 2005 to $2015\left(R^{2}=0.56\right.$ for the USA and $R^{2}=0.45$ for the European Union). Modern renewable energy grew particularly fast despite higher costs. Private statistical data with regard to the energy business in the USA during 2007-2015 indicate that the sales of modern renewable energy were low when the prices were high in $2007^{4}$. Solar power cost was USD 2.67 per kilowatt-hour, which is more than 50 times costlier than wind power, which in turn was twice as expensive as hydropower; hydropower is about as costly as power based on fossil fuels. Costs decreased when sales grew: sales of solar power grew on average by $160 \%$ along with the decrease of unit costs by $-48 \%$ on average, wind power by $25 \%$ and $-6 \%$ and hydropower by $0.6 \%$ and $-0.7 \%$, respectively. Sales of solar power and wind power grew although price parity with hydropower was not attained by 2015, which indicates high appreciation for modern renewable energy and fast cost-reducing technological change. Such data for the European Union is not found, but the appreciation is also observed with regard to the growing cross-country correlations between electricity prices and renewable energy share in electricity consumption during that period of time (from $R^{2}=-0.11$ in 2004 to +0.34 in 2015).

Electricity deliveries to households in the USA and the European Union enlarged along with higher prices and lower costs of energy resources, which generated a larger value added of electricity services. These changes are not observed in businesses. The growing value added of energy services is related to the sales of modern renewable energy, which grow despite the lower prices of the alternatives. This is an indication of consumers' appreciation for modern renewable energy.

\section{Incentives for innovations}

The valorisation of energy services generates incentives for innovations indicating opportunities for profitable sales. The value added of all electricity services, this means for households and businesses, has increased yearly by $\mathrm{USD}_{2005} 2.4$ billion in the USA and $\mathrm{USD}_{2005}$
6.7 billion in the European Union, respectively. That large income after subtracting the costs of resources generated substantial incentives for novel qualities entailing a diversification of energy services. The sum of the value added has enlarged by $\mathrm{USD}_{2005} 9.2$ billion on an annual average, which is equivalent to five times all expenditures on research, development and demonstration with regard to energy efficiency and renewable energy in these countries [49].

An observation is that the energy services diversify. A growing market refers to the distributed energy systems, usually based on modern renewable energy. The global capacity of distributed energy systems is estimated to have achieved 109.9 GW in 2015 and $125.9 \mathrm{GW}$ in 2016, which is equivalent in value to USD 65.8 billion and USD 69.7 billion, excluding wind power, combined heat power and energy storage [50]. Including batteries, measured by power, the global distributed energy systems grew by $22 \%$ on annual average from 2006 to 2016 . In 2016, the market value of distributed systems approached USD 200 billion measured by the batteries; about half of that capacity was in the USA [51]. Batteries are preferred for storage despite the lower costs of alternatives, for instance, water storage [52]. Water storage as a technology for energy storage is presently used in large-scale reservoirs, but not as distributed energy systems although it is possible to be used on a smaller scale, for instance, for energy storage in communities.

Innovations also cover the equipment for information and communication, so-called smart grids. The smart grids, distribution automation and smart metering systems in the USA grew from nil to about USD 3.3 billion a year during the period from 2007 to 2015 . These sales were lower than $1 \%$ of the total electricity sales in 2015 but grew by $17 \%$ on annual average when compared to about $1.0 \%$ growth of all electricity sales ${ }^{5}$. Other studies show a $23 \%$ growth of distributed energy, water heating, lighting, electronic appliances and demand response for information systems in the USA during that period of time (https://www.greentechmedia. $\mathrm{com} / \mathrm{articles} / \mathrm{read} /$ u.s.-advanced-energy-revenue-grewby-just-1-in-2016). Renewable energy technologies are also tuned to the specific markets; PV and wind power are, for example, integrated in construction when aiming to reduce space use or to prevent negative impacts to nature and landscape. Reliable valuations of such innovations, however, are not found. Statistical data on the distributed energy systems in the European Union are not available, but there is progress regarding many local energy initiatives and the European Union directive that facilitates them [53].

The valorisation of energy services generates incentives for innovation which invokes the diversification of energy services. The innovations are presently focused on distributed energy systems. 


\section{Global valorisation trends}

It was assessed using the IEA data whether the valorisation of energy services has evolved in the 14 countries mentioned above and globally during the period from 1990 to 2015, as well as specifically during the unfavourable conditions for renewable energy from 1990 to 2005 and during the favourable conditions from 2005 to 2015. Trends were estimated, meaning average growth rates during those periods of time. These trends cover energy intensity, electricity consumption and energy consumption per capita, as well as the share of all renewable energies in energy consumption, the share of modern renewable energy in energy consumption and $\mathrm{CO}_{2}$ emissions. The valorisation of energy services is shown by comparison of the trends per country. Higher growth rates of energy intensity and electricity consumption compared to energy consumption per capita indicate the valorisation. Higher growth of the shares of all renewable energies and the modern one in energy consumption compared to energy intensity and electricity consumption points to their contribution to the valorisation. In addition, a higher growth of modern renewable energy than the $\mathrm{CO}_{2}$ emissions points to its contribution to emission reduction. “Appendix 2" presents a number of countries where valorisation is observed and the cross-country correlations between those trends. Whereas the former indicates whether the valorisation is widespread, the latter shows whether the trends across countries are similar or diverge.

\section{Valorisation across countries}

Table 4 shows the data in 2015 and the average growth in the period from 1990 to 2015; the growth rates during 1990-2005 and 2005-2015 are also estimated and discussed beneath but not presented in the Table.

Energy consumption varies across countries. Energy intensity range has spread four times from $0.27 \mathrm{USD}_{2005}$ per kilowatt-hour in Ethiopia to $1.19 \mathrm{USD}_{2005}$ per kilowatt-hour in the Philippines, whereas electricity consumption per capita has spread 150 times from $86 \mathrm{kWh}$ in Ethiopia to $13.0 \mathrm{MWh}$ in the USA and energy consumption per capita has spread 14 times from 2.6 MWh in Bangladesh to 81.3 MWh in the USA. Energy intensity grew in all countries except Brazil, as well as electricity consumption in all countries and energy consumption per capita in all countries except the high-income ones and the Russian Federation. Energy intensity has grown faster than energy consumption per capita in 9 out of 14 countries and globally throughout the whole period, in seven countries and globally during 1990-2005 and in 10 countries and globally during 2005-2015. Higher fuel prices triggered higher energy intensity. Electricity consumption grew faster than energy consumption per

Table 4 Energy intensity, electricity consumption, energy consumption, share of all renewable energy and modern renewable energy and $\mathrm{CO}_{2}$ emissions in 2015 as well as average growth from 1990 to 2015

\begin{tabular}{|c|c|c|c|c|c|c|c|c|c|c|c|c|}
\hline & \multicolumn{2}{|c|}{$\begin{array}{l}\text { Energy } \\
\text { intensity }\end{array}$} & \multicolumn{2}{|c|}{$\begin{array}{l}\text { Electricity } \\
\text { consumption }\end{array}$} & \multicolumn{2}{|c|}{ Energy consumption } & \multicolumn{2}{|c|}{ All renewables } & \multicolumn{2}{|c|}{$\begin{array}{l}\text { Modern } \\
\text { renewables }\end{array}$} & \multicolumn{2}{|c|}{$\begin{array}{l}\text { CO2 emission in energy } \\
\text { consumption }\end{array}$} \\
\hline & $\begin{array}{l}\text { USD/ } \\
\mathrm{kWh}\end{array}$ & $\begin{array}{l}\text { Aver. } \\
\text { growth }\end{array}$ & $\begin{array}{l}\text { kWh/ } \\
\text { cap }\end{array}$ & $\begin{array}{l}\text { Aver. } \\
\text { growth }\end{array}$ & $\begin{array}{l}\text { kWh/ } \\
\text { cap }\end{array}$ & Aver. growth & Share & Aver. growth & Share & $\begin{array}{l}\text { Aver. } \\
\text { Growth }\end{array}$ & $\mathrm{kg} / \mathrm{kWh}$ & Aver. growth \\
\hline & 2015 & $\begin{array}{l}1990- \\
2015(\%)\end{array}$ & 2015 & $\begin{array}{l}1990- \\
2015(\%)\end{array}$ & 2015 & $\begin{array}{l}1990- \\
2015(\%)\end{array}$ & 2015 (\%) & 1990-2015 (\%) & $2015(\%)$ & $2015(\%)$ & 2015 & 1990-2015 (\%) \\
\hline Globally & 0.7 & 1.6 & 3052 & 1.1 & 21,642 & 0.5 & 14 & 0.2 & 1.5 & 5.2 & 0.23 & 0.09 \\
\hline United States & 0.2 & 0.2 & 12,833 & 0.9 & 79,107 & -0.4 & 7 & 1.1 & 1.4 & 2.8 & 0.21 & -0.2 \\
\hline Japan & 0.9 & 1.0 & 7864 & 0.8 & 39,359 & -0.2 & 6 & 2.5 & 1.5 & 3.2 & 0.24 & 0.6 \\
\hline $\begin{array}{l}\text { European } \\
\text { Union }\end{array}$ & 0.9 & 1.7 & 5968 & 1.0 & 36,205 & -0.4 & 14 & 4.6 & 2.9 & 11.7 & 0.19 & -0.4 \\
\hline $\begin{array}{l}\text { Russian } \\
\text { Federation }\end{array}$ & 0.4 & 1.4 & 6588 & 0.7 & 57,278 & -0.7 & 3 & 0.2 & 0.0 & 12.1 & 0.20 & -0.3 \\
\hline Mexico & 0.9 & 1.1 & 2231 & 2.4 & 17,974 & 0.3 & 8 & -1.3 & 2.2 & -1.5 & 0.21 & 0.0 \\
\hline Brazil & 0.9 & -0.3 & 2506 & 0.5 & 16,606 & 1.7 & 41 & -0.6 & 0.9 & 18.3 & 0.22 & -0.2 \\
\hline China & 0.5 & 4.7 & 4047 & 4.2 & 25,218 & 4.3 & 9 & -3.8 & 1.6 & 31.6 & 0.29 & -0.2 \\
\hline Indonesia & 1.0 & 1.5 & 823 & 4.8 & 10,176 & 1.9 & 33 & -1.3 & 7.7 & 5.5 & 0.24 & 0.4 \\
\hline Philippines & 1.1 & 1.9 & 749 & 2.5 & 6061 & 0.5 & 59 & -1.9 & 18.4 & 0.4 & 0.26 & 0.6 \\
\hline India & 0.7 & 2.3 & 859 & 2.2 & 7550 & 2.5 & 25 & -2.4 & 0.6 & 24.0 & 0.28 & 0.0 \\
\hline Nigeria & 0.6 & 2.1 & 144 & 1.9 & 8898 & 0.4 & 80 & 0.1 & 0.0 & 0.0 & 0.20 & -0.2 \\
\hline Pakistan & 0.8 & 0.9 & 488 & 1.4 & 5781 & 0.9 & 38 & -0.9 & 0.1 & 0.0 & 0.21 & -0.1 \\
\hline Bangladesh & 1.1 & 0.9 & 326 & 5.1 & 2738 & 2.7 & 25 & -3.1 & 0.0 & 0.0 & 0.20 & 0.0 \\
\hline Ethiopia & 0.3 & 3.3 & 86 & 5.3 & 5850 & 0.2 & 94 & -0.1 & 0.0 & -0.6 & 0.22 & 0.0 \\
\hline
\end{tabular}


capita in 11 countries and globally throughout the whole period, in 11 countries and globally during 1990-2005 and in 8 countries and globally during 2005-2015. High fuel prices did not trigger electricity consumption across those countries. Energy intensity and electricity consumption are correlated to the energy consumption per capita across countries during 1990-2005, which points to similar trends across the countries, but they are not correlated within the period from 2005 to 2015 and throughout the period from 1990 to 2015, which points to diverging trends. The valorisation of energy services is widespread though the trends diverge across the countries. The impacts of higher fuel prices on the valorisation were mixed because they triggered energy intensity but not electricity consumption.

The consumption of renewable energy also varies. All renewable energy in 2015 covered about 14\% of the global energy consumption in 2015 (4\% lower than shown in the World Bank data) which varied from $3 \%$ in the Russian Federation to $94 \%$ in Ethiopia. Modern renewable energy covered about $1.5 \%$ of the global energy consumption in 2015, which varied from nil in low-income countries to $18.4 \%$ in the Philippines and $7.7 \%$ in Indonesia, mainly geothermal energy, and $2.9 \%$ in the European Union, mainly wind power and solar power. The decreasing share of all renewable energy is a trend in all countries except the three high-income countries and Brazil. Its growth is slower than the growth of energy intensity and electricity consumption in most countries and correlated negatively. Modern renewable energy consumption tends to grow globally, but does not grow in the low-income countries that primarily use biofuel. Growth is very high in China, India, Brazil, Russian Federation and the European Union. The growth rates of modern renewable energy were higher than the energy intensity in eight countries and globally, and these two correlate throughout the period from 1990 to 2015. They were higher than electricity consumption in nine countries and globally and correlate during 1990-2005, not during 2005-2015, but throughout the period 1990-2015. Total $\mathrm{CO}_{2}$ emissions grew globally but decreased in five countries. The growth of modern renewable energy is higher than the growth of $\mathrm{CO}_{2}$ emissions in nearly all countries and (negatively) correlated throughout the years 19902015. The contribution of modern renewable energy to the valorisation is widespread across the countries. That contribution grew in most countries with the exception of low-income counties, where the consumption of biomass and hydro resources increased.

The valorisation of energy services evolved in most countries and globally, and modern renewable energy contributed to that and to $\mathrm{CO}_{2}$ emission reduction. The global energy market is evolving from fossil fuels to renewable energy and from traditional renewable energy resources to the modern ones.

\section{Extrapolation of the growth rates}

The trends during 1990-2015 are extrapolated to 20152040 which means that the average growth rates of income, energy consumption, renewable energy and $\mathrm{CO}_{2}$ emissions during the past 25 years are assumed to continue in the future 25 years without any change. It is assessed whether the growth of modern renewable energy enables $\mathrm{CO}_{2}$ emission reduction. Opinions about such continuity differ. Some experts expect that renewable energy grows toward nearly zero fossil fuel consumption within a few decades due to the cost-effective technologies [54] and social innovations in energy consumption [55], but other experts doubt such a possibility with regard to the persistence of vested technologies [56] and obstructive interests and deficiencies in novel renewable energy technologies [57]. The presented extrapolations solely show the impacts of the past trends without suggesting realities although, in general, the past trends are good predictors of future patterns as breakthrough changes on a global scale are rare. Whether the past trends continue in the far future is to be seen. Important factors, herewith, are progress in renewable energy technologies, diffusion of distributed energy systems with energy storage and policies that foster an entry of cost-effective innovations with price incentives rather than erect regulations to protect costly vested interests.

From the extrapolations, it could be assumed that in energy consumptions, fossil fuels are being gradually substituted for renewable energy. In the calculations, therefore, the extrapolated supplies of coal, oil, gas and nuclear are reduced by the sum of extrapolated biofuels, hydropower and modern renewable energy; that reduction is associated with the resource share in total fossil fuel supplies. Energy production and consumption are assumed to be in balance every year in each country, which does imply no storage nor international trade although they are possible and cost-effective in practice. $\mathrm{CO}_{2}$ emissions are based on the remaining fossil fuels (calculated with the IEA factors 3.80 ton $\mathrm{CO}_{2}$ per ton coal, 2.52 ton $\mathrm{CO}_{2}$ per ton oil, 2.20 ton $\mathrm{CO}_{2}$ per ton oil equivalent of gas; all other energy resources nil $\mathrm{CO}_{2}$ emissions). As a verification of these factors, it was found that the calculated global $\mathrm{CO}_{2}$ emissions deviated $1.2 \%$ from the IEA data for 2015 although the deviations are larger for a few countries; the reasons for these deviations are unknown. Two extrapolations were calculated: one for the case that the average growth of renewable energy of the countries in the period from 1990 to 2015 continued without any change during 2015-2040, which is plausible in the case where renewable energy technologies become more cost-effective; and another one for the case that the average growth of modern renewables saturates and other growth rates do not change. This saturation is calculated as a linear decline of the average growth for the period from 1990 to 2015 as 
being $25 \%$ of that in 2040, which approximates a logistic function of market share in time. This extrapolation is plausible in the case where vested interests obstruct innovations and policies decrease efforts in mitigation of the climate change. All calculations are done per country each year. In Table 5, the results are given as indices of 2015 in 2040 (fossil fuels are not shown as they are related to renewable energy).

Both extrapolations demonstrate a 3.8 times larger global real income in 2040 than in 2015 and a 2.0 times larger global energy consumption although the latter decreases in the high-income countries despite larger GDP. Smaller differences between the countries' income and energy consumption can be expected. Modern renewable energy is the main contributor to global renewable energy and $\mathrm{CO}_{2}$ emission reduction. As a result of growing renewable energy, China has become the largest global energy producer, followed by India and the European Union.

In the first extrapolation, modern renewable energy would grow globally about 103 times in 2040 compared to 2015 . That global growth would be faster than the average growth in the European Union during the past 25 years but slower than the average growth in China, India and Brazil during the last 25 years. Global consumption of fossil fuels in 2040 might be reduced by $48 \%$ compared to 2015, whereas the global $\mathrm{CO}_{2}$ emissions might be reduced by $54 \%$ compared to the 2015 level. It would be $46 \%$ of the 2015 level or $15 \%$ below the 1990 level, which is needed for the mitigation of climate change. $\mathrm{Nil} \mathrm{CO}_{2}$ emission would be attained in China, India, and
Ethiopia. A sensitivity assessment based on the growth rates during 1990-2005, it is when the conditions for renewable energy were unfavourable, does not change this outcome significantly. In the second extrapolation, modern renewable energy would grow nearly 10 times by 2040, whereas global growth rates would be lower than the average ones during last 25 years in the European Union. Global consumption of fossil fuels would be reduced in 2040 by $15 \%$, and global $\mathrm{CO}_{2}$ emissions would be reduced by $18 \%$ compared to the 2015 level, which means $82 \%$ of the 2015 level. Both extrapolations suggest that growth of income and energy consumption does not preclude a substantial emission reduction of $\mathrm{CO}_{2}$ if modern renewable energy technologies are disseminated due to higher value energy services and policy incentives.

If renewable energy is pursued during the next few decades at a similar pace as during the last decades, global $\mathrm{CO}_{2}$ emissions would be sufficiently reduced for a climate change mitigation. This emission reduction would be attained along with higher income and energy consumption. Modern renewable energy would become the key global energy resource, whereas China, India and the European Union were the largest energy producers.

\section{Discussion and conclusion}

Global energy consumption grows along with shifts from fossil fuels to renewable energy, as well as from the traditional renewable energy resources based on biomass and hydropower to modern renewable energy based on

Table 5 Extrapolations of income, energy consumption, modern renewable energy and $\mathrm{CO}_{2}$ emission index

\begin{tabular}{|c|c|c|c|c|c|c|}
\hline \multirow{3}{*}{$\begin{array}{l}\text { Compared to } \\
2015=100\end{array}$} & \multirow{2}{*}{$\begin{array}{l}\text { Income } \\
\text { USD_PPP } \\
\text { per capita }\end{array}$} & \multirow{2}{*}{$\begin{array}{l}\text { Energy consumed } \\
\text { kWh per capita }\end{array}$} & \multicolumn{2}{|c|}{ Continuing growth 1990-2015 } & \multicolumn{2}{|c|}{ Decreasing growth 1990-2015 } \\
\hline & & & $\begin{array}{l}\text { All renewable energy, } \\
\text { indexed share of } 2015\end{array}$ & $\mathrm{CO}_{2}$ percent of 2015 & $\begin{array}{l}\text { All renewable energy, } \\
\text { indexed share of } 2015\end{array}$ & $\begin{array}{l}\mathrm{CO}_{2} \text { percent } \\
\text { of } 2015\end{array}$ \\
\hline & 2040 & 2040 & 2040 & 2040 & 2040 & 2040 \\
\hline World & 378 & 201 & 10,263 & 46 & 990 & 79 \\
\hline USA & 183 & 114 & 165 & 109 & 153 & 110 \\
\hline Japan & 125 & 98 & 217 & 90 & 205 & 91 \\
\hline European Union & 145 & 97 & 540 & 23 & 348 & 53 \\
\hline Russian Federation & 118 & 82 & 102 & 89 & 94 & 90 \\
\hline Mexico & 196 & 151 & 113 & 147 & 112 & 147 \\
\hline Brazil & 196 & 213 & 424 & 71 & 225 & 205 \\
\hline China & 938 & 349 & 50,884 & - & 4076 & - \\
\hline Indonesia & 301 & 220 & 308 & 166 & 198 & 230 \\
\hline Philippines & 250 & 156 & 149 & 153 & 124 & 206 \\
\hline India & 427 & 254 & 1476 & - & 304 & 268 \\
\hline Nigeria & 329 & 203 & 214 & 155 & 214 & 197 \\
\hline Pakistan & 247 & 207 & 187 & 210 & 187 & 228 \\
\hline Bangladesh & 327 & 267 & 135 & 296 & 135 & 335 \\
\hline Ethiopia & 407 & 205 & 416 & - & 416 & - \\
\hline
\end{tabular}


geothermal, wind and solar energy. Despite high costs, modern renewable energy has increased three times faster than energy consumption during the years from 1990 to 2005 which is in the period when the conditions for renewable energy were unfavourable because the prices for fossil fuels were low and policy support was limited. They increased ten times faster during the years from 2005 to 2015 in which the conditions improved as the prices increased and the policy support grew. The factors that caused these shifts during the period from 1990 to 2015 were assessed for the 14 largest countries, whereas the European Union was assumed as one country. The prices of fossil fuels, policy support for renewable energy and cost-effective renewable energy technologies do not explain this growth because modern renewable energy rarely reached a price parity with fossil fuels before 2015. An important additional factor for that growth is the innovation for valuable qualities in energy services.

The growth of modern renewable energy is driven by entrepreneurs that pursue qualities in energy services perceived valuable by customers. In effect, the value added of energy services increases, referred to as the valorisation of energy services. In addition to heat, power, motion, light, sound and other valuable qualities of energy services, modern renewable energy enables access to remote areas, flexible production and autonomy in consumption, as well as jobs, income, security and suchlike benefits for the individual and collective interests. Modern renewable energy grows when the benefits of its qualities outweigh the costs of supplies as perceived by customers; the growth is enhanced when the conditions for renewable energy are favourable. The European Union was particularly successful compared to the USA and Japan. The innovators, herewith, were rarely the vested firms in electricity and gas business. Of more importance were social initiatives and small firms that generated know-how, procurement, policy support and other facilities which enabled the growth of business focused on modern renewable energy and distributed energy systems. Herewith, social initiatives created conditions for an entry of innovators despite higher costs than those of the competitors as the innovations in energy services deliver value-adding qualities. How policies can foster beneficial uses of renewable enery and whether this is applicable to other technologies should be studied.

The valorisation of electricity services for households is noticed in the USA and the European Union during 20052015. Although the sale prices of electricity were manifold higher than the purchase prices of energy resources, electricity prices at households increased along with larger deliveries of electricity, whereas the purchase prices decreased; this is not observed in industries. In effect, the value added of energy services to households and industries together grew on average by $2.0 \%$ per year in the USA and $2.8 \%$ in the European Union, respectively, which was mainly driven by the growing share of modern renewable energy. Those growth rates are equivalents of the additional values of $\mathrm{USD}_{2005} 3$ billion in the USA and $\mathrm{USD}_{2015} 6$ billion in the European Union on average per year. Together it is about five times larger market exenditure than all annual expenditures for research, development and demonstration in the fields of energy efficiency and renewable energy in those countries. Hence, the valorisation of energy services generated incentives for innovations that diversify energy services toward distributed energy systems, electricity storage in batteries, customization of energy technologies and emission reduction of $\mathrm{CO}_{2}$.

The valorisation of energy services due to modern renewable energy is observed in most countries. Higher income can be generated along with lower $\mathrm{CO}_{2}$ emissions when fossil fuels are substituted for modern renewable energy. If a countries' average growth rates in the period from 1990 to 2015 are extrapolated to the period from 2015 to 2040, global income per capita would increase four times, energy consumption per capita twice, and renewable energy would grow 100 times along with the $\mathrm{CO}_{2}$ emission reduction to $46 \%$ in the 2015 level. This would be $15 \%$ lower emission than the $\mathrm{CO}_{2}$ emission observed in 1990, which is targeted for the mitigation of climate change. This is plausible for the cases in which the innovations do continue due to diverse energy services and cost-effective technologies. When the growth rates of modern renewable energy gradually decline because innovations are obstructed, global renewable energy would grow only tenfold and $\mathrm{CO}_{2}$ emission would be reduced to $82 \%$ of the 2015 level. In both extrapolations, income and energy consumption, renewable energy supplies and emission reduction would change a lot across countries and energy production would shift to China, India, Brazil and the European Union.

The valorisation of energy services is rarely studied. Although it is briefly covered in this paper, a few lessons can be learned. A lesson for energy businesses is that markets diversify and evolve toward high-value energy services. A lesson for innovators is that even costly energy technologies disseminate when valuable qualities are added and are facilitated by social initiatives that allow for beneficial applications. Finally, a lesson for policy making is that the valorisation of energy services due to renewable energy does generate growth of income along with a far-reaching emission reduction of $\mathrm{CO}_{2}$ when policies foster sustainable innovations by putting a high price on $\mathrm{CO}_{2}$.

\section{Methods}

All methods used for the analysis are presented in the "Background" section. 


\section{Endnotes}

${ }^{1}$ https://www.eia.gov/electricity/data.php\#avgcost is used until 2012, then extrapolated and corrected based on the US Energy Information Administration, Short-Term Energy Outlook Real and Nominal Prices 2017 https://www.eia.gov/outlooks/steo/realprices/. Prices for coal are similar but for oil and gas somewhat different.

${ }^{2}$ For instance, the production prices as a percentage of the consumer prices in 2015 varied from 20\% in Denmark to $84 \%$ on Malta, the network prices from $11 \%$ on Cyprus to $45 \%$ in Romania and taxes from $5 \%$ on Malta to $61 \%$ in Denmark based on the Eurostat https:// ec.europa.eu/eurostat/data/database.

${ }^{3}$ The following scales are assumed for households: below $1000 \mathrm{kWh}$ annual consumption is $10 \%$ of the total, 1000-2500 kWh 20\%, 2500-5000 kWh 40\%, $5000-10,00020 \%$ and above $10,000 \mathrm{kWh}$ per year $10 \%$ of the sum. The assumed scale for industries are: below
20 MWh $10 \%$ of the total, $20-500$ MWh 10\%, 500-2000 MWh 20\%, 2000-20,000 MWh 30\%, 20,000-70,000 MWh 20\%, 70,000-150,000 MWh 10\%. The estimation method of Eurostat is unclear based on the Eurostat https://ec.europa.eu/eurostat/data/database.

${ }^{4}$ https://www.statista.com/statistics/289149/revenuesolar-power-industry-united-states, accessed 21 Aug 2017. Sales prices are calculated as sales divided by deliveries; the sales are assumed equivalent of revenues.

${ }^{5}$ This statistic defines distributed energy systems as inventory of several technologies: small scale photovoltaic, local electricity and heat grids, energy storage, electric vehicles, charging stations, demand management and measuring systems; sometimes local biofuels, wind power and co-generation are included. https://www.statista.com/statistics/222082/projected-us-smart-grid-market-size, accessed 21 Aug 2017.

\section{Appendix 1}

Table $\mathbf{6}$ Selected data with regard to the global economy, energy consumption and supplies

\begin{tabular}{|c|c|c|c|c|}
\hline \multicolumn{5}{|c|}{ Indicators of economy and energy based on IEA data } \\
\hline World & 2015 & 1990-2015 (\%) & 1990-2005 (\%) & 2005-2015 (\%) \\
\hline Population million & 7334 & 1.3 & 1.4 & 1.2 \\
\hline GDP billion USD 2010 & 75,449 & 2.8 & 2.9 & 2.7 \\
\hline GDP PPP billion USD & 105,035 & 3.4 & 3.2 & 3.6 \\
\hline Energy production Mtoe & 13,790 & 1.8 & 1.8 & 1.8 \\
\hline Energy consumption Mtoe & 13,647 & 1.8 & 1.8 & 1.7 \\
\hline Electric consumption TWh & 22,386 & 2.9 & 2.9 & 2.9 \\
\hline $\mathrm{CO} 2 \mathrm{Mt}$ & 32,294 & 1.8 & 1.9 & 1.8 \\
\hline Coal & 3839 & 2.2 & 2.0 & 2.5 \\
\hline all liquids & 4334 & 1.2 & 1.4 & 0.8 \\
\hline Gas & 2944 & 2.3 & 2.4 & 2.2 \\
\hline Nuclear & 671 & 1.1 & 2.3 & -0.7 \\
\hline Biofuels & 1324 & 1.5 & 1.5 & 1.6 \\
\hline Hydro & 334 & 2.4 & 2.1 & 2.9 \\
\hline Geothermal, wind and solar energy & 201 & 7.1 & 4.4 & 11.1 \\
\hline Total energy & 13,646 & 1.8 & 1.8 & 1.7 \\
\hline Only fossil fuels & 11,788 & 1.8 & 1.87 & 1.6 \\
\hline Only renewable & 1859 & 2.0 & 1.70 & 2.5 \\
\hline \multicolumn{5}{|l|}{ Indicators } \\
\hline GDP PPP/capita & 14,322 & 2.0 & 1.8 & 2.4 \\
\hline Elec cons kWh/capita & 3,052 & 1.6 & 1.5 & 1.7 \\
\hline $\mathrm{CO}_{2} \mathrm{Mt} / \mathrm{Mtoe}$ prod & 2.34 & 0.0 & 0.0 & 0.0 \\
\hline $\mathrm{CO}_{2} \mathrm{t} /$ capita & 4.40 & 0.5 & 0.5 & 0.6 \\
\hline Energy efficiency USD/kWh & 0.66 & 1.6 & 1.4 & 1.9 \\
\hline Electricity in all & $14 \%$ & 1.1 & 1.1 & 1.2 \\
\hline $\mathrm{CO}_{2} \mathrm{~kg} / \mathrm{kWh}$ fossil fuels & 0.23 & 0.09 & -0.01 & 0.3 \\
\hline Energy cons kWh/cap & 21,642 & 0.5 & 0.4 & 0.5 \\
\hline Share renewable energy & $14 \%$ & 0.2 & -0.1 & 0.8 \\
\hline Share modern renewable energy & $1.5 \%$ & 5.2 & 2.5 & 9.3 \\
\hline
\end{tabular}




\section{Appendix 2}

Table $\mathbf{7}$ Indicators of the valorization of energy services across fourteen countries and globally

\begin{tabular}{|c|c|c|c|c|}
\hline Number of countries included globally & Periods & $\begin{array}{l}\text { Number of countries } \\
\text { that indicate valorisation }\end{array}$ & Correlations $R^{2}$ & Percent confirmed (\%) \\
\hline \multirow[t]{3}{*}{ Energy intensity and energy consumption per capita } & $1990-2015$ & 10 & -0.03 & 67 \\
\hline & 1990-2005 & 8 & 0.58 & 53 \\
\hline & $2005-2015$ & 11 & 0.07 & 73 \\
\hline \multirow[t]{3}{*}{ Electricity consumption and energy consumption per capita } & 1990-2015 & 12 & 0.02 & 80 \\
\hline & 1990-2005 & 12 & 0.66 & 80 \\
\hline & $2005-2015$ & 9 & 0.19 & 60 \\
\hline \multirow[t]{3}{*}{ Share all renewable energy and energy intensity } & 1990-2015 & 4 & -0.33 & 27 \\
\hline & 1990-2005 & 2 & -0.33 & 13 \\
\hline & $2005-2015$ & 3 & -0.13 & 20 \\
\hline \multirow[t]{3}{*}{ Share all renewable energy and electricity consumption } & 1990-2015 & 3 & -0.58 & 20 \\
\hline & $1990-2005$ & 2 & -0.67 & 13 \\
\hline & $2005-2015$ & 3 & -0.27 & 20 \\
\hline \multirow[t]{3}{*}{ Share modern renewable energy and energy intensity } & 1990-2015 & 9 & 0.41 & 60 \\
\hline & $1990-2005$ & 9 & 0.80 & 60 \\
\hline & $2005-2015$ & 7 & -0.34 & 47 \\
\hline \multirow[t]{3}{*}{ Share modern renewable energy and electricity consumption } & $1990-2015$ & 10 & -0.06 & 67 \\
\hline & 1990-2005 & 9 & 0.06 & 60 \\
\hline & $2005-2015$ & 7 & -0.22 & 47 \\
\hline \multirow[t]{3}{*}{ Modern renewable energy and $\mathrm{CO}_{2}$ emissions } & 1990-2015 & 11 & -0.31 & 73 \\
\hline & 1990-2005 & 11 & -0.22 & 73 \\
\hline & $2005-2015$ & 12 & -0.13 & 80 \\
\hline
\end{tabular}

\section{Additional file}

Additional file 1: Benefits of renewable energy. (DOCX $21 \mathrm{~kb}$ )

\section{Acknowledgments}

I highly appreciated comments of Kamia Handayani and Mira Krozer, as well as of three unknown referees. I am grateful to Mansi Jain and Editors of the journal for the language checks and adaptations.

This paper is in memory of prof.dr. Andries Nentjes, a founding father of environmental economics and trailblazer of renewable energy.

\section{Funding}

There is no external funding involved in the study and publication.

\section{Availability of data and materials}

All data are open source. They are available on request.

\section{Authors' contributions}

All work is done by the author of this publication. The author read and approved the final manuscript.

\section{Ethics approval and consent to participate}

There are no ethical issues related to the analysis and publication of this paper as no people participate in the study which includes solely statistical analyses.

\section{Consent for publication}

Herewith, I confirm my agreement on publication of this paper in Energy,

Sustainability and Society. I am the main and sole author of this paper.

\section{Competing interests}

The author declares that he has no competing interests.

\section{Publisher's Note}

Springer Nature remains neutral with regard to jurisdictional claims in published maps and institutional affiliations.

\section{Author details}

${ }^{1}$ University of Twente, CSTM, Enschede, the Netherlands. ${ }^{2}$ Jyothy Institute of Technology, Bangalore, India. ${ }^{3}$ Sustainable Innovations Academy, Amsterdam, the Netherlands.

Received: 5 September 2018 Accepted: 12 February 2019

Published online: 20 March 2019

\section{References}

1. https://data.worldbank.org/indicator, accessed 6 Jul 2018.

2. https://www.iea.org/statistics/ accessed 6 Jul 2018.

3. Frankfurt School-UNEP (2017) Global trends in renewable energy. Bloomberg, Frankfurt 
4. https://www.eia.gov/outlooks/aeo/electricity_generation.php, accessed 25 Jul 2018.

5. Lancaster KJ (1966) A new approach to consumer theory. J Polit Econ 74(2): 132-157

6. Schumpeter JA $(1935,1989)$ Business cycles. Porcupine Press, Philadelphia, p 59

7. Krozer $Y$ (2015) Theories and practices on innovations for sustainable development. Springer, Dordrecht/Heidelberg

8. http://ec.europa.eu/eurostat/data/database, accessed 6 Jul 2018.

9. Kalimeris P, Richardson C, Bithas K (2014) A meta-analysis investigation of the direction of the energy-GDP causal relationship: implications for the growth-degrowth dialogue. J Cleaner Prod 67:1-13

10. WEC (2010) Energy efficiency: a recipe for success. World Energy Council, London

11. https://www.eia.gov/totalenergy/data/annual/index.php, accessed 6 Jul 2018

12. https://www.enerdata.net/publications/executive-briefing/world-energyexpenditures.html, accessed 15 Mar 2017.

13. http://www.iea.org/bookshop/729-CO2_Emission_from_Fuel_Combustion, accessed 26 Jul 2017.

14. Krozer Y, Nentjes A (2006) An essay on innovations for sustainable development. Environ Sci 3(3):163-174

15. Nordhaus W (1973) The allocation of energy resources. Brook Pap Econ Act 1973(3):529-576

16. Shafiee S, Topal E (2010) A long term view on fossil fuel prices. Appl Energy 87:988-1000

17. Morriss AP Meiners RE (2016) Competition in global oil markets: a metaanalysis and review. http://secureenergy.org/wp-content/uploads/2016/02/ SAFE_Competition-in-Global-Oil-Markets-A-Meta-Analysis-and-Review.pdf, accessed 25 Jul 2018.

18. Dinica V (2003) Sustained diffusion of renewable energy. University Press, Enschede

19. IEA (2017) World Energy Outlook 2017, http://www.iea.org/weo2017, accessed 9 May 2018.

20. Clements B, Coady D, Fabrizio S, Alleyne T, Sdralevich C (2013) Energy subsidies reform: lessons and implications. International Monetary Fund, Frankfurt

21. Coady D, Parry I, Sears I, Shang B (2015) How large are global subsidies. International Monetary Fund WP15/105, Frankfurt

22. EEA (2004) Energy subsidies in the European Union. Technical report 1/ 2004, Copenhagen

23. Alberici S, Boeve S, Breevoort van P, Deng Y, Förster S, Gardiner A, Gastel van V, Grave K, Groenenberg H, de Jager D, Klaassen E, Pouwels W, Smith M, de Visser E, Winkel T, Wouters K (2014) Subsidies and costs of EU energy. Ecofys, full-dataset-energy-costs-and-subsidies-eu28-across-powergeneration-technologies, accessed 1 Jun 2018.

24. Haas R, Panzer C, Resch G, Ragwitz M, Reece G, Held A (2011) A historical review of promotion strategies for electricity from renewable energy sources in EU countries. Renew Sustain Energy Rev 15:1003-1034

25. Jacobsson S, Johnson A (2000) The diffusion of renewable energy technology: an analytical framework and key issues for research. Energy Policy 28:625-640

26. Hekkert MP, Suurs RAA, Negro O, Kuhlman S, Smits REHM (2007) Functions of innovations system: a new approach for analysing technological change. Tech Forecasting Soc Chang 74:413-432

27. Allen R (2012) Backward into the future, The shift to coal and implications for the next energy transition. Energy Policy 50:17-23

28. Herman R, Ardekanin SA, Ausubel JH (1989) Dematerialization. In: Ausubel $\mathrm{JH}$, Sladovich HE (eds) Technology and environment, 1st edn. National Academy Press, Washington DC, pp 50-69

29. Grubler A (2012) Energy transition research, insight and cautionary tales. Energy Policy 50:8-16

30. Hirth $L$ (2013) The market value of variable renewable, The effect of solar wind power variability on their relative price. Energy Econ 38:218-236

31. Watanabe $\mathrm{CH}$, Griffy-Brown $\mathrm{CH}$, Zhu B, Nagamatsu A (2002) Inter-firm technology spillover and the "virtous cycle" of photovoltaic development in Japan. In: Grübler A, Nakicenovic N, Nordhaus WD (eds) Technological change and the environment, resources for the future, pp 127-159

32. Doyne Farmer J, Lafond F (2016) How predictable is technological progress? Res Policy 45:647-665

33. Rubin ES, Azevedo IML, Jaramillo P, Yeh S (2015) A review of learning rates for electricity supply technologies. Energy Policy 86:198-218
34. Ciarreta A, Espinoza MP, Pizarro-Irizar C (2014) Is green energy expensive? Empirical evidence from the Spanish electricity markets. Energy Policy 69: 205-215

35. Gianfreda A, Parisio L, Pelagatti M (2016) Revisiting long-run relations in power markets with high RES penetration. Energy Policy 94:432-445

36. Inglesi-Lotz R (2016) The impact of renewable energy consumption to economic growth: a panel data application. Energy Econ 53:58-63

37. Vaona A (2016) The effect of renewable energy generation on imports. Renew Energy 86:354-359

38. https://www.census.gov/data/tables/2015/econ/susb/2015-susb-annual.html, accessed 16 Jul 2018.

39. http://www.stat.go.jp/english/data/jigyou/index.html, accessed 16 Jul 2018.

40. Pernick R, Wilder C (2008) The cleantech revolution, 1st edn. Harper, New York

41. Rubino J (2009) Clean money, picking the winners in the green-tech room, 1 st edn. John Wiley \& Sons, New Jersey

42. Ornetzeder M, Rohracher H (2006) User-led innovations and participation processes: lessons from sustainable energy technologies. Energy Policy 34: $138-150$

43. Krozer Y (2012) Renewable energy in European regions. Int J Innov Reg Dev 4:44-59

44. Krozer Y (2018) Energy initiatives in Europe. In: Visa I, Duca A (eds) Nearly zero energy communities. Springer International Publisher AG, Heidelberg

45. Labandeira X, Labeaga JM, Lopez-Otero X (2015) A meta-analysis on the price elasticity of energy demand. University de Vigo WP04/2015, Frankfurt

46. Arora V (2014) Estimates of the price elasticity of the natural gas supply in the United States, https://mpra ub.uni-muenchen de/54232/, accessed 12 Jun 2017

47. Saygin D, Worrel E, Patel MK, Gielen DJ (2011) Potential of best practice technologies to improve energy efficiency in the global chemical and petrochemical sector. Energy 36:5579-5790

48. Fouquet $R$ (2014) Long run demand for energy services: income and price elasticities over two hundred years. Rev Environ Econ Policy 8:186-207

49. OECD statistics, Total RD\&D, Group 1. Energy efficiency. https://stats.oecd. org/ accessed 24 Jul 2018 and corrected for inflation in USD 2005

50. https://www.navigantresearch.com/research/distributed-energy-resourcesglobal-forecast; access 7 Jun 2017

51. REN21 (2017) Renewables 2017 global status report. Paris Ren Secretariate.

52. Lazard (2016) Lazard levelized costs of energy analysis-version 20.0. accessed 17 Aug 2017

53. Council of the European Union (2018) Proposal for a Directive of the European Parliament and of the Council on the promotion of the use of energy from renewable sources, paragraph $16 \mathrm{e}, 16 \mathrm{ter}, 16 \mathrm{~g}$ as well as 52-55, Brussels, Interinstitutional File 2016/0382 (COD), https://www.parlament.gv. at/PAKT/EU/XXVI/EU/02/77/EU_27793/imfname_10822563.pdf, accessed 21 Aug 2018.

54. Deng YY, Blok K, van der Leun K (2012) Transition to a fully sustainable global energy system. Energ Strat Rev 1:109-121

55. Sovacool BK (2016) How long will it take, conceptualizing the temporary dynamics of energy transition. Energy Res Soc Sci 13:202-215

56. Grubler A, Wilson C, Nemet G (2016) Appels, oranges and consistent comparison of temporary dynamics of energy transition. Energy Policy 22: $18-25$

57. Fouquet R (2016) Historical energy transition: speed, prices and system transformation. Energy Policy 22:7-12

Ready to submit your research? Choose BMC and benefit from:

- fast, convenient online submission

- thorough peer review by experienced researchers in your field

- rapid publication on acceptance

- support for research data, including large and complex data types

- gold Open Access which fosters wider collaboration and increased citations

- maximum visibility for your research: over $100 \mathrm{M}$ website views per year

At BMC, research is always in progress.

Learn more biomedcentral.com/submissions 